\title{
Increased binding and defective migration across fibronectin of cycling hematopoietic progenitor cells
}

Olivier Giet, Dirk R. Van Bockstaele, Ivano Di Stefano, Sandra Huygen, Roland Greimers, Yves Beguin, and André Gothot

\begin{abstract}
Engraftment of hematopoietic progenitor cells has been shown to decrease during cell cycle transit. We studied cell cycleassociated changes in adhesion and migration of mitotically activated cord blood $\mathrm{CD} 4^{+}$cells. Migration toward medium conditioned by the stromal-derived factor1-producing cell line MS-5 was studied in bovine serum albumin- and fibronectin (Fn)-coated transwells. Migration was reduced in cycling CD $34^{+}$cells and longterm culture-initiating cells (LTC-ICs) compared with their noncycling counterparts across Fn but not across bovine serum
\end{abstract}

albumin. Conversely, Fn binding was higher in cycling $\mathrm{CD}_{3} 4^{+}$cells and LTC-ICs compared with noncycling progenitor cells, while adhesion of both subsets to bovine serum albumin was undetectable. The contribution of $\alpha 4$ and $\alpha 5$ integrins in mediating adhesion and migration of activated $\mathrm{CD}_{34}{ }^{+}$cells onto $\mathrm{Fn}$ was analyzed by neutralization experiments. While $\alpha 4$ mediated Fn binding decreased during $\mathrm{G}_{2} / \mathrm{M}, \alpha 5$ integrin-mediated adhesion increased during transit from $G_{0} / G_{1}$ to $S$ and $G_{2} / M$ phases. As for migration, the contribution of $\alpha 4$ integrin was similar in all phases, whereas $\alpha 5$-directed migration was lower in $G_{2} / M$ compared with $G_{0} / G_{1}$ and $S$ phases. Defective migration of cycling $\mathrm{CD} 4^{+}$cells was not due to differences in $\alpha 5$ integrin expression. In conclusion, chemotaxis across $\mathrm{Fn}$ is less efficient in cycling progenitor cells in correlation with an increased Fn binding capacity. In addition, $\alpha 4$ and $\alpha 5$ integrin functions are independently modulated during cell cycle transit. (Blood. 2002;99: 2023-2031)

() 2002 by The American Society of Hematology

\section{Introduction}

Recent studies have indicated that entry of cultured hematopoietic stem cells (HSCs) into active phases of the cell cycle reduces their homing ability and subsequent long-term repopulating potential. First, several investigators reported an engraftment defect of stem cells that had been induced to cycle either in vivo or ex vivo. ${ }^{1-4}$ Habibian et $\mathrm{al}^{5}$ later demonstrated that murine stem cells transiting through $\mathrm{S}$ and $\mathrm{G}_{2}$ phases acquired an engraftment defect that was reversible after the completion of mitosis. Szilvassy et $\mathrm{al}^{6}$ also observed a loss of long-term engraftment associated with cell cycle activation. As for human stem cells, we showed that transition from $\mathrm{G}_{0}$ to $\mathrm{G}_{1}$ of a first cell cycle resulted in a decrease of engraftment capacity in immunodeficient mice. ${ }^{7}$ Also, Glimm et $\mathrm{al}^{8}$ provided evidence that expanded human HSCs were ineffective in repopulation assays during $S$ and $\mathrm{G}_{2} / \mathrm{M}$ phases. To date, the explanation at the cellular and/or molecular level of these findings has not been provided.

Specific interactions of HSCs with adhesion molecules expressed by endothelial and stromal cells have been studied by numerous groups. A model of HSC homing has progressively emerged. ${ }^{9,10}$ After initial rolling on endothelial $\mathrm{E}$ and $\mathrm{P}$ selectins, HSCs adhere to the luminal face of bone marrow endothelial cells through very late antigen (VLA)-4/vascular cell adhesion molecule-1 and lymphocyte function-associated antigen-1/intercellular cell adhesion molecule-1 interactions. Adherent HSCs transmigrate through the basal lamina via interactions of surface VLA-4 and

From the Departments of Medicine/Hematology, Laboratory Medicine, and Pathology, University of Liège, Belgium; and Laboratory of Experimental Hematology, University of Antwerp, Belgium.

Submitted July 19, 2001; accepted November 1, 2001.

Supported by grants from the National Fund for Scientific Research (Brussels, Belgium), the University of Liège Center against Cancer, and the Belgian Federation against Cancer. O.G. and S.H. were supported by Télévie fellowships. Y.B. and A.G. are Research Director and Associate Scientist,
VLA-5 with fibronectin (Fn). HSCs undergo chemotactic intramedullary migration in response to stromal-derived factor (SDF)-1 to reach adequate "niches" formed by bone marrow stromal cells expressing, among other ligands, vascular cell adhesion molecule-1 ${ }^{11,12}$ and Fn. ${ }^{13}$

Fn is recognized by 2 different $\beta 1$ integrins expressed by HSCs: VLA-4 and VLA-5. Previous studies have highlighted a dominant role either for VLA-4 ${ }^{14}$ or for VLA-5 ${ }^{15}$ in Fn binding of HSCs. Interaction of HSCs with $\mathrm{Fn}$ is a tightly regulated process controlled by cytokines such as stem cell factor (SCF), interleukin-3, and thrombopoietin, ${ }^{16-19}$ which have been reported to modulate both VLA-4 and VLA-5 during short-term ex vivo culture, influencing adhesion ${ }^{20,21}$ and migration onto Fn-coated surfaces. ${ }^{22}$ Also, Fn was reported to enhance transmigration of $\mathrm{CD} 4^{+}$cells toward SDF- $1 .{ }^{23}$ Altogether, not only Fn is present in key areas traversed by HSCs during the homing process ${ }^{24}$ but, also, interactions of HSC with Fn are modulated through changes in integrin affinity or expression by a vast number of stimuli and therefore present a broad potential for modulation. Therefore, an interesting working hypothesis was to test whether cell cyclerelated differences in homing were related to regulation of Fn binding.

Relationships between cell cycle transit and integrin expression and/or function were suggested by several investigators, ${ }^{25,26}$ including our group. ${ }^{27}$ In nonhematopoietic tissues, it has been well respectively, of the National Fund for Scientific Research.

Reprints: André Gothot, University of Liège, Laboratory Hematology, CHU Sart Tilman B35, 13, avenue de l'Hôpital, B-4000 Liège, Belgium; e-mail: agothot@ulg.ac.be.

The publication costs of this article were defrayed in part by page charge payment. Therefore, and solely to indicate this fact, this article is hereby marked "advertisement" in accordance with 18 U.S.C. section 1734.

(C) 2002 by The American Society of Hematology 
established that when adhesion is maximal cells are immobilized and unable to migrate, while lower adhesion force may allow cell locomotion. ${ }^{28-30}$ In this paper, we investigated whether adhesion and migration of committed progenitor cells and primitive longterm culture-initiating cells (LTC-ICs) were modulated by cell cycle transit. Our data show that migration across Fn is defective while static adhesion to Fn is increased in cycling progenitor cells as compared with their noncycling counterparts.

\section{Materials and methods}

\section{Cells}

After obtaining informed consent, cord blood (CB) samples were obtained following full-term vaginal delivery according to the guidelines established by the Ethical Committee of the University of Liège. Mononuclear lowdensity cells were isolated by centrifugation over Ficoll-Paque (Amersham Pharmacia Biotech, Uppsala, Sweden). CB CD34+ cells were purified by immunomagnetic selection using magnetic-activated cell separation CD34 isolation kits (Miltenyi Biotech, Auburn, CA) as per the manufacturer's instructions. $\mathrm{CD} 34^{+}$cell purity in the final product always exceeded $97 \%$.

\section{Short-term suspension cultures}

$\mathrm{CD} 4^{+}$cells were plated in a serum-free medium consisting of Iscoves medium supplemented with $10 \mu \mathrm{g} / \mathrm{mL}$ bovine serum albumin (BSA), 10 $\mu \mathrm{g} / \mathrm{mL}$ bovine insulin, $200 \mu \mathrm{g} / \mathrm{mL}$ transferrin (all from Stem Cell Technologies, Vancouver, BC), $2 \mathrm{mM}$ alanyl-glutamine, $1 \%$ (vol/vol) cholesterolrich lipids, $1 \mathrm{mM}$ sodium pyruvate (all from Sigma, St Louis, MO), 100 $\mathrm{U} / \mathrm{mL}$ penicillin, $100 \mu \mathrm{g} / \mathrm{mL}$ streptomycin, and $5 \times 10^{-2} \mathrm{mM} 2$-mercaptoethanol (all from Biowhittaker, Petit-Rechain, Belgium). Cells were stimulated by a combination of $100 \mathrm{ng} / \mathrm{mL}$ SCF (Amgen, Thousand Oaks, CA), $50 \mathrm{ng} / \mathrm{mL}$ thrombopoietin (Amgen), and $100 \mathrm{ng} / \mathrm{mL}$ flt3-ligand (FL; R\&D Systems, Abingdon, United Kingdom) and maintained at $37^{\circ} \mathrm{C}$ in a $100 \%$ humidified atmosphere with $5 \% \mathrm{CO}_{2}$. The percentage of $\mathrm{CD} 34^{+}$cells up to 48 hours in culture was always more than $95 \%$.

\section{MS-5 conditioned medium}

The stromal MS-5 cell line ${ }^{31}$ was plated in $25 \mathrm{~cm}^{2}$ flasks in $7 \mathrm{~mL}$ $\alpha$-minimum essential medium ( $\alpha$-MEM; Biowhittaker) supplemented with $10 \%$ fetal bovine serum (Life Technologies, Paisley, United Kingdom) at $37^{\circ} \mathrm{C}$. At confluence, the medium was completely replaced with fresh medium. After 7 days, the conditioned medium (MS-5 CM) was harvested, spun at $2000 \mathrm{~g}$ for 10 minutes, and the supernatant frozen in small aliquots. Concentration of SDF-1 in MS-5 CM was assayed using the Quantikine human SDF-1 immunoassay kit (R\&D Systems). The kit cross-reacts with mouse SDF-1 whose amino acid sequence is $99 \%$ homologous to that of human SDF-1. SDF-1 concentration was on average $76.5 \pm 7.5 \mathrm{ng} / \mathrm{mL}$ in MS-5 CM batches used for these studies.

\section{Migration assays}

Migration assays were performed in $6.5-\mathrm{mm}$ diameter $5-\mu \mathrm{m}$ pore transwells (Costar, Cambridge, MA). Transwell filters were coated with $10 \mu \mathrm{g} / \mathrm{cm}^{2} \mathrm{Fn}$ (Sigma) in phosphate-buffered saline (PBS; Biowhittaker). Control filters were coated with $1 \%$ fraction V BSA (Life Technologies) in PBS. Coating was done overnight at $4^{\circ} \mathrm{C}$. The coating solution was aspirated and replaced by a $1 \%$ BSA solution in PBS at $37^{\circ} \mathrm{C}$ for 30 minutes to block nonspecific binding sites. After 2 washes in RPMI 1640 with HEPES $25 \mathrm{mM}, 2 \times 10^{5}$ cells were plated in $100 \mu \mathrm{L}$ Myelocult (Stem Cell Technologies) in the upper chamber of the transwell. The bottom compartment was filled with $600 \mu \mathrm{L}$ MS-5 CM or $\alpha$-MEM with $10 \%$ fetal bovine serum as control medium. After incubation at $37^{\circ} \mathrm{C}$ during 3 hours, nonmigrating and migrating cells were harvested from the top and bottom compartments, respectively. Nonmigrating cells were recovered by 2 washes each consisting of a 5-minute treatment with an enzyme-free cell dissociation buffer (Life Technologies) at $37^{\circ} \mathrm{C}$ followed by vigorous pipetting. In some experiments, nonmigrating cells remaining loosely adherent to the interface filter or floating in the upper chamber (ie, nonadherent cells) were separately harvested from cells that were firmly adherent to the filter (ie, adherent cells). Nonadherent cells were recovered by 2 gentle washes with PBS $1 \%$ BSA, and adherent cells were harvested after a 5-minute treatment with cell dissociation buffer. Harvested cells in all fractions were counted in Fuchs-Rosenthal hemacytometers (total volume $3.2 \mu \mathrm{L}$ ). The percentage of cells in each fraction was calculated relative to the total number of cells plated. In selected experiments, stimulated $\mathrm{CD} 34^{+}$cells were preincubated with neutralizing antibodies against VLA-4 (clone P4C2, Life Technologies), VLA-5 (clone P1D6, Life Technologies), CXCR4 (clone 12G5, Pharmingen, San Diego, CA), or isotype-matched mouse immunoglobulin $\mathrm{G}(\mathrm{IgG})$ (Pharmingen) during 30 minutes at $4^{\circ} \mathrm{C}$ prior to the migration assay.

\section{Adhesion assays}

Fn (Sigma) was adsorbed at $4^{\circ} \mathrm{C}$ to wells of nontissue culture-treated 24-well plates (Becton Dickinson, Erembodegem, Belgium) at $10 \mu \mathrm{g} / \mathrm{cm}^{2}$, except where indicated, in PBS. Coating was done in the same conditions as described above for transwell filters, after which $1 \times 10^{5}$ to $2 \times 10^{5}$ cultured CD $34^{+}$cells were plated in RPMI 1640 containing $0.1 \%$ BSA at $37^{\circ} \mathrm{C}$. After 1-hour incubation, nonadherent cells were harvested by 2 standardized washes using warm PBS $1 \%$ BSA. Adherent cells were then recovered after a 5-minute incubation in cell dissociation buffer at $37^{\circ} \mathrm{C}$ followed by vigorous pipetting. Adherent and nonadherent cells were counted in Fuchs-Rosenthal hemacytometers. Percent adhesion was calculated relative to the total number of cells plated. Adhesion on BSA-coated control plates was less than $2 \%$. In some experiments, CD34 ${ }^{+}$cells were preincubated with blocking antibodies anti-VLA-4, anti-VLA-5, or control mouse $\mathrm{IgG}$ during 30 minutes at $4^{\circ} \mathrm{C}$ prior to the adhesion assay.

\section{Determination of adhesion and migration of $\mathrm{CD}_{3} 4^{+}$cells in different phases of the cell cycle}

Cells recovered in various fractions after adhesion or migration assays were incubated in PBS 0.6\% IGEPAL CA-630 (Sigma) containing $50 \mu \mathrm{g} / \mathrm{mL}$ propidium idodide (PI) and $1 \mathrm{mg} / \mathrm{mL}$ ribonuclease (Boehringer, Mannheim, Germany). After a 30-minute incubation on ice in the dark, cells were run on a FACSort flow cytometer collecting FL-2 channel values. The percentage of cells in the different phases of the cell cycle was determined with Modfit software (Becton Dickinson). Absolute numbers of adherent cells in $\mathrm{G}_{0} / \mathrm{G}_{1}, \mathrm{~S}$, or $\mathrm{G}_{2} / \mathrm{M}$ were obtained by multiplying the percentage of adherent cells by the percentage of cells in $\mathrm{G}_{0} / \mathrm{G}_{1}, \mathrm{~S}$, or $\mathrm{G}_{2} / \mathrm{M}$ in the adherent fraction. The same procedure was used to obtain numbers of $\mathrm{G}_{0} / \mathrm{G}_{1}, \mathrm{~S}$, and $\mathrm{G}_{2} / \mathrm{M}$ cells in the nonadherent, migrating, and nonmigrating fractions. The migratory activity of cells in $\mathrm{G}_{0} / \mathrm{G}_{1}, \mathrm{~S}$, and $\mathrm{G}_{2} / \mathrm{M}$ was calculated from the ratio of the absolute number of migrating cells in $\mathrm{G}_{0} / \mathrm{G}_{1}$, $\mathrm{S}$, or $\mathrm{G}_{2} / \mathrm{M}$ and the total number of cells (migrating plus nonmigrating) in $\mathrm{G}_{0} / \mathrm{G}_{1}, \mathrm{~S}$, or $\mathrm{G}_{2} / \mathrm{M}$. Similarly, binding capacity of cells in $\mathrm{G}_{0} / \mathrm{G}_{1}$, S, and $\mathrm{G}_{2}+\mathrm{M}$ was obtained by dividing the number of adherent cells in $\mathrm{G}_{0} / \mathrm{G}_{1}, \mathrm{~S}$, or $\mathrm{G}_{2}+\mathrm{M}$ by the total number of cells (adherent plus nonadherent) in the corresponding phase.

\section{Colony-forming cell and LTC-IC assays}

Colony-forming cell assays were performed in Methocult H4435 (Stem Cell Technologies), which is supplemented with $50 \mathrm{ng} / \mathrm{mL} \mathrm{SCF}, 20 \mathrm{ng} / \mathrm{mL}$ granulocyte-macrophage colony-stimulating factor, $20 \mathrm{ng} / \mathrm{mL}$ interleukin-3, $20 \mathrm{ng} / \mathrm{mL}$ interleukin- $6,20 \mathrm{ng} / \mathrm{mL}$ granulocyte colony-stimulating factor, and $3 \mathrm{U} / \mathrm{mL}$ erythropoietin. Absolute frequencies of LTC-ICs in cell suspensions recovered after migration assays were determined by limiting dilution analysis over M2-10B4 fibroblast feeder cells. ${ }^{32}$ Briefly, the fibroblast feeder cell line M2-10B4 (American Type Culture Collection, Rockville, MD) was cultured in RPMI 1640 with $10 \%$ FCS. Cells were irradiated at $50 \mathrm{~Gy}$ and plated in 96-well plates at 15000 cells per well in $100 \mu$ L Myelocult (Stem Cell Technologies). Within a week, test cells were plated in limiting dilution at 24 wells per cell dose in another $100 \mu \mathrm{L}$ Myelocult and maintained at $33^{\circ} \mathrm{C}$ in a $100 \%$ humidified atmosphere containing $5 \% \mathrm{CO}_{2}$, with weekly half-medium change. After 5 to 6 weeks, 
medium was carefully aspirated from each well, followed by the addition of $200 \mu \mathrm{L}$ Methocult H4435. After an additional 2 weeks, wells were scored for the presence or absence of hematopoietic colonies, and the frequency of LTC-ICs was calculated using the maximum likelihood estimator. ${ }^{33}$

To determine the percent migration of cycling and noncycling LTC-ICs, hydroxyurea (HU) killing tests were performed as previously described, ${ }^{27}$ prior to migration assays. Briefly, $1 \times 10^{5}$ to $2 \times 10^{5} \mathrm{CD} 34^{+}$cells were treated with $2 \mathrm{mg} / \mathrm{mL} \mathrm{HU}$ (Sigma) in Iscoves medium with $1 \%$ BSA during 1 hour at $37^{\circ} \mathrm{C}$. Control cells were incubated in medium only. After 2 washes in Iscoves medium with $1 \% \mathrm{BSA}$, cells were transferred in transwells and allowed to migrate during 3 hours. Exposition of the cells to $\mathrm{HU}$ did not interfere with migration $(37.9 \% \pm 4.5 \%$ migration in $\mathrm{HU}$ treated cells vs $36.6 \% \pm 4.5 \%$ migration in control cells, $n=7$ ). HU did not modify VLA-4, VLA-5, and CXCR4 expression or alter adhesion to Fn (data not shown). Migrating and nonmigrating cells were then replated in limiting dilution in LTC-IC assays. In each fraction, the percentage of cycling LTC-ICs was estimated from the proportion of LTC-ICs killed by HU treatment relative to the percentage of LTC-ICs in control cells. Migration of cycling LTC-ICs was calculated from the ratio of the number of cycling LTC-ICs in the migrating fraction and the total number (migrating plus nonmigrating) of cycling LTC-ICs. Similarly, to calculate the migratory activity of noncycling LTC-ICs, the number of noncycling LTC-ICs in the migrating fraction was divided by the total number (migrating plus nonmigrating) of noncycling LTC-ICs.

\section{Flow cytometric analysis of integrin and CXCR4 expression}

Fluorescein isothiocyanate (FITC)-conjugated anti-VLA-4 (CD49d, Coulter Immunotech, Marseille, France) and FITC-conjugated anti-VLA-5 (CD49e, Pharmingen) were used in combination with phycoerythrin (PE)conjugated anti-CXCR4 (Pharmingen). Cells were incubated with antibodies or isotype-matched control IgG for 20 minutes on ice in the dark. Cells were washed in PBS 1\% calf serum (Biowhittaker) and fixed in PBS 1\% paraformaldehyde (Sigma). Data were acquired on a FACSort flow cytometer (Becton Dickinson) and analyzed using CellQuest software (Becton Dickinson). $\mathrm{CXCR}^{+}$cells were identified as those displaying a fluorescence above $99 \%$ of the isotypic control. Integrin density was expressed as the mean channel fluorescence ratio (MCFR) defined as MCF of integrin expression divided by MCF of fluorescence-matched isotypic control.

\section{Flow cytometric cell sorting}

Cultured CD $34^{+}$cells were sorted on the basis of cell cycle status. Briefly, cells were incubated in serum-free medium supplemented with $5 \mu \mathrm{g} / \mathrm{mL}$ Hoechst 33342 (Molecular Probes, Eugene, OR) during 30 minutes at $37^{\circ} \mathrm{C}$. Cells in $\mathrm{G}_{0} / \mathrm{G}_{1}$ or in $\mathrm{S} / \mathrm{G}_{2} / \mathrm{M}$ were sorted by a FACS Vantage (Becton Dickinson) equipped with a multiline UV laser (Innova Enterprise Ion Laser, Coherent, Santa Clara, CA) (351-364 nm) providing excitation for Hoechst. Hoechst signal was detected through a $424 \pm 22 \mathrm{~nm}$ bandpass filter. The purity of sorted cells was confirmed by DNA staining of sorted cells with PI and always exceeded $90 \%$.

For cell sorting on the basis of VLA- 5 expression, cultured CD34 ${ }^{+}$cells were labeled with biotinylated anti-VLA-5 (clone VC5; Pharmingen) and with streptavidin-FITC (Pharmingen), each step for 20 minutes at $4^{\circ} \mathrm{C}$. Gating was set to include the lower and upper $20 \%$ of the VLA-5 histogram. Contamination between VLA- $5^{\text {low }}$ and VLA- $5^{\text {high }}$ fractions was $5 \%$ to $10 \%$. In selected experiments where $\mathrm{CD} 34^{+}$cells were sorted simultaneously according to the level of VLA-5 expression and cell cycle status, Hoechst 33342 was added to anti-VLA-5-stained cells at the final concentration of 5 $\mu \mathrm{g} / \mathrm{mL}$ during 30 minutes at $37^{\circ} \mathrm{C}$, prior to cell sorting.

\section{Statistical analysis}

Results are reported as mean \pm standard error of the mean (SEM). Comparisons were made using Student $t$ tests. All $P$ values are 2-sided.

\section{Results}

\section{Effect of fibronectin on the motility of cell cycle-activated} progenitor cells

It has been well established that $\mathrm{CB}$ progenitor cells reside in the $\mathrm{G}_{0} / \mathrm{G}_{1}$ phase of the cell cycle when freshly isolated. ${ }^{34} \mathrm{~A} 48$-hour ex vivo culture in the presence of SCF, thrombopoietin, and FL was used to induce a large proportion of the cells into active phases of the cell cycle ( $>40 \%$ of cells in $S / G_{2} / M$ in all experiments). The cloning efficiency of stimulated $\mathrm{CD}_{3} 4^{+}$cells was estimated in methylcellulose assays and was $90.5 \% \pm 1.8 \%(n=21)$. This must be compared with the cloning efficiency of freshly isolated CB CD $34^{+}$cells, which was $40.5 \% \pm 3.5 \%$ in historical controls. An increase in cloning efficiency after a short-term cytokine stimulation has been observed repeatedly in our laboratory and is due to the loss of nonclonogenic cells quickly after culture initiation. The use of a highly pure population of clonogenic progenitors was essential to ascertain that the cells being studied were at the same level of differentiation.

Migratory activity of cultured $\mathrm{CD} 34^{+}$cells was assayed in transwells (Figure 1). Spontaneous migration toward control medium was observed in $5.5 \% \pm 1.4 \%$ and $18.0 \% \pm 2.0 \%$ of the cells through BSA- and Fn-coated filters, respectively $(P<.05)$. Migration toward MS-5 CM was increased up to $26.0 \% \pm 3.4 \%$ through BSA $(P<.05$ compared with control medium) and up to $41.0 \% \pm 3.3 \%$ through Fn $(P<.05$, compared with control medium). Therefore, migration of stimulated $\mathrm{CD} 4^{+}$cells was dependent both on a chemoattractant gradient and on the presence of an adhesive substratum.

We confirmed that migration toward MS-5 CM was dependent on the presence of SDF-1. The expression of SDF-1 receptor, CXCR4, was measured by FACS analysis in cells recovered in the migrating and nonmigrating fractions (Figure 2). Migration toward MS-5 CM was, in part, dependent on the presence of CXCR4 because $46.1 \% \pm 5.6 \%$ of the cells migrating through an Fn interface were $\mathrm{CXCR}^{+}$as compared with $23.6 \% \pm 4.4 \%$ for nonmigrating cells $(P<.05, \mathrm{n}=7)$. As negative control, spontaneous migration toward control medium was not related to differences in CXCR4 expression: $26.6 \% \pm 6.9 \%$ of migrating and $29.6 \% \pm 5.6 \%$ of nonmigrating cells were $\mathrm{CXCR} 4^{+}$, respectively

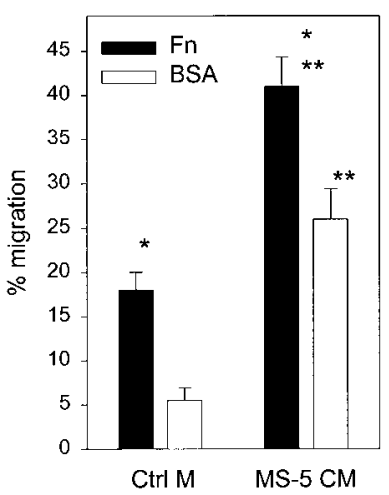

Figure 1. Transmigration of ex vivo-cultured CD $34^{+}$cells toward MS-5 CM was enhanced by Fn. CB CD $34^{+}$progenitor cells were stimulated ex vivo during 48 hours and transferred to the top chamber of transwells coated with Fn $\left(10 \mu \mathrm{g} / \mathrm{cm}^{2}\right)$ or BSA (1\%). MS- 5 CM or control medium ( $\alpha$-MEM with $10 \%$ fetal bovine serum) was placed in the bottom chamber. Cells were allowed to migrate during 3 hours at $37^{\circ} \mathrm{C}(n=6)$. ${ }^{*}$ Percent migration was higher across Fn than across BSA $(P<.05) .{ }^{*} \mathrm{MS}-5 \mathrm{CM}$ stimulated migration across both matrices $(P<.05)$. 
A
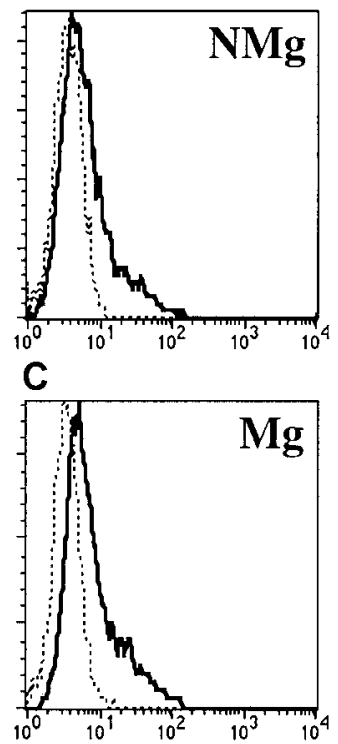

Ctrl M
B

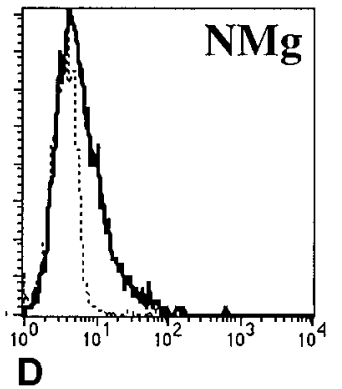

D

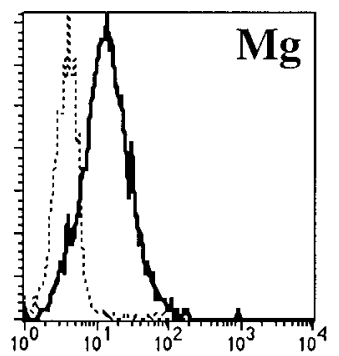

MS-5 CM

Figure 2. Transmigration of cultured $\mathrm{CD}_{3} 4^{+}$cells was dependent on the expression of CXCR4. CB CD34+ progenitor cells were stimulated ex vivo during 48 hours and assayed for transmigration across Fn-coated filters toward control medium $(A, C)$ or MS-5 CM $(B, D)$. Expression of CXCR4 was measured by FACS analysis in nonmigrating $(A, B)$ and migrating cells $(C, D)$. Staining with irrelevant isotypematched IgG-PE (dotted lines) and anti-CXCR4-PE (solid lines) is shown in a representative experiment (of 7 ).

$(P>.05)$. Migration toward MS-5 CM was inhibited by a neutralizing antibody against CXCR4, across either Fn (48.5\% inhibition) or BSA (52.6\% inhibition).

To better characterize the effect of Fn, cells remaining in the top chamber after 3 hours of transmigration were fractionated into nonadherent and adherent fractions. Less than $2 \%$ adherent cells could be recovered from a BSA-coated filter $(\mathrm{n}=10)$. In contrast, in the presence of $10 \mu \mathrm{g} / \mathrm{cm}^{2} \mathrm{Fn}, 10.8 \% \pm 1.6 \%(\mathrm{n}=14)$ of input cells were strongly adherent to the transwell filter. With increasing Fn concentrations (Figure 3), the proportion of migrating cells rose from $27.9 \%$ to $44.9 \%$, together with the appearance of an adherent fraction (up to $12.9 \%$ of total input cells at a $20 \mu \mathrm{g} / \mathrm{cm}^{2} \mathrm{Fn}$

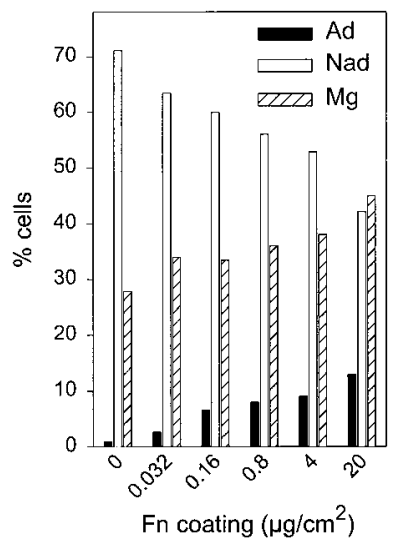

Figure 3. Effect of Fn coating concentration on adhesion and migration of cultured $\mathrm{CD}_{3}{ }^{+}$cells. Transmigration of cultured $\mathrm{CD} 34^{+}$cells was determined toward MS-5 CM across filters coated at the indicated Fn concentrations. After 3 hours, cells were recovered in 3 fractions: migrating $(\mathrm{Mg})$ as well as nonadherent (Nad) and adherent (Ad) nonmigrating cells. A representative experiment (of 2) is depicted.

concentration). Thus, at high Fn concentrations, although the proportion of migrating cells increased, a significant percentage of nonmigrating cells was fully adherent to the transwell filter.

The expression of VLA-4 and VLA-5 integrins was analyzed in adherent, nonadherent, and migrating $\mathrm{CD} 34^{+}$cells coexpressing CXCR4. VLA-4 was brightly expressed by most of the cells $(>99 \%)$ in all 3 fractions and with similar MCFR (data not shown). Small differences were observed in VLA-5 antigen density among the 3 fractions: MCFR of VLA-5 was $3.6 \pm 0.7$ in the nonadherent fraction, $4.7 \pm 0.8$ in adherent cells, and $2.8 \pm 0.2$ in the migrating fraction $(P<.05$ compared with adherent cells, $\mathrm{n}=5$ ) (Figure 4). Therefore, the inability of a subset of CD34 ${ }^{+}$ $\mathrm{CXCR}^{+}$cells to migrate across Fn was not caused by downregulation of either VLA-4 or VLA-5. On the contrary, VLA-5 was slightly overexpressed in the adherent fraction.

\section{Adhesion and migration of cycling progenitor cells are inversely correlated}

We next studied Fn binding and migratory activity of activated CB $\mathrm{CD}_{3}{ }^{+}$cells in relation with cell cycle status. Following adhesion assay, the cell cycle status of adherent and nonadherent cells was established by DNA staining with PI $(n=18)$. The adhesion
A
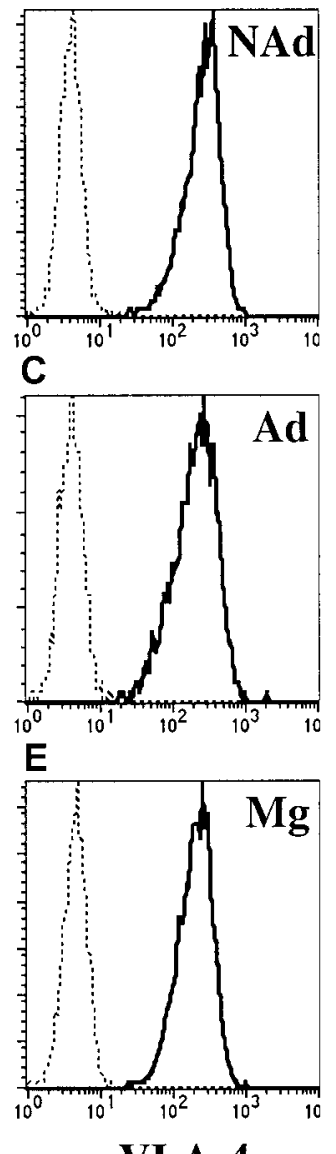

B
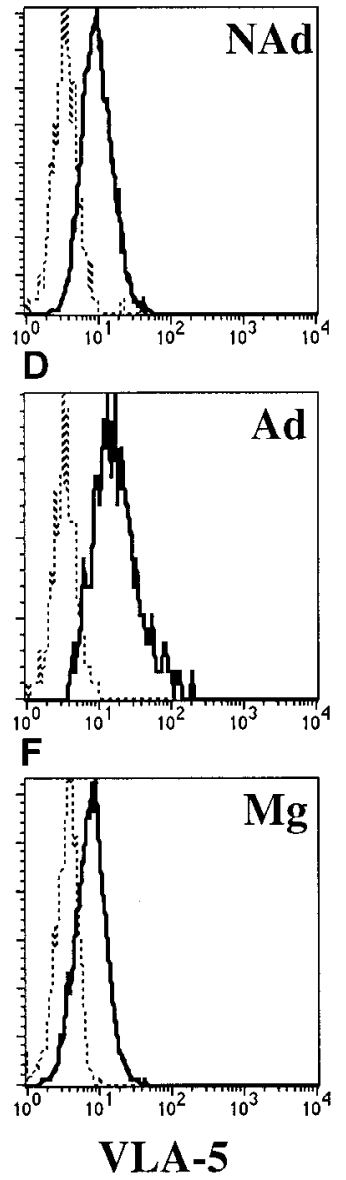

Figure 4. Expression of VLA-4 and VLA-5 integrins in $\mathrm{CXCR} 4^{+}$nonadherent, adherent, and migrating CD $34^{+}$cells. Transmigration of cultured $\mathrm{CD} 34^{+}$cells was assessed across Fn-coated filters, after which nonadherent $(A, B)$, adherent $(C, D)$, and migrating cells $(E, F)$ were harvested. Cells were labeled with anti-CXCR4-PE together with anti-VLA-4-FITC or anti-VLA-5-FITC. Analysis of integrin expression was restricted to CXCR4-expressing cells by appropriate gating. Staining with isotype-matched IgG (dotted lines) and with anti-VLA-4 (left plots) or anti-VLA-5 (right plots) is shown in a representative experiment out of 5 . 
capacity to $\mathrm{Fn}$ of $\mathrm{CB} \mathrm{CD}_{3}{ }^{+}$cells increased with cell cycle progression: $14.7 \% \pm 2.6 \%$ in $\mathrm{G}_{0} / \mathrm{G}_{1}, 18.7 \% \pm 2.7 \%$ in $\mathrm{S}(P<.05$ compared with $\left.\mathrm{G}_{0} / \mathrm{G}_{1}\right)$ and $31.5 \% \pm 4.6 \%$ in $\mathrm{G}_{2} / \mathrm{M}(P<.05$ compared with both $\mathrm{G}_{0} / \mathrm{G}_{1}$ and $\mathrm{S}$ ) (Figure $5 \mathrm{~A}$ ). Adhesion to a BSA-coated plate was always less than $2 \%$.

The same experimental design was used to assess the migratory activity of stimulated $\mathrm{CB}$ CD $34^{+}$cells in different phases of the cell cycle. Following migration assay toward MS-5 CM in an Fn-coated transwell, cells recovered from the top and bottom chambers were assayed for cell cycle status by FACS analysis. Migration decreased with cell cycle progression: $44.5 \% \pm 2.5 \%$ in $\mathrm{G}_{0} / \mathrm{G}_{1}$, $39.1 \% \pm 3.2 \%$ in $\mathrm{S}\left(P<.05\right.$ compared with $\left.\mathrm{G}_{0} / \mathrm{G}_{1}\right)$, and $31.0 \% \pm 2.7 \%$ in $\mathrm{G}_{2} / \mathrm{M}\left(P<.05\right.$ compared with both $\mathrm{G}_{0} / \mathrm{G}_{1}$ and $\left.\mathrm{S}\right)$ (Figure 5B). This was not due to an inhibitory effect of MS-5 CM on the cycling status of migrating $\mathrm{CD} 34^{+}$cells. Indeed, in control experiments, when stimulated $\mathrm{CD} 34^{+}$cells were incubated for 3 hours in MS-5 CM, the proportion of cells in $S / G_{2} / M$ $(47.0 \% \pm 0.3 \%)$ was not different from that of cells incubated in control medium $(46.9 \% \pm 1.0 \%, \mathrm{n}=2)$. Moreover, when the filter was coated with BSA, migration toward MS-5 CM was similar in all phases of the cell cycle $\left(26.9 \% \pm 3.7 \%\right.$ in $\mathrm{G}_{0} / \mathrm{G}_{1}, 30.5 \% \pm 3.1 \%$ in $\mathrm{S}$, and $26.4 \% \pm 5.2 \%$ in $\mathrm{G}_{2} / \mathrm{M}$, Figure $5 \mathrm{C}$ ). These results demonstrate that Fn overall facilitated transmigration of activated $\mathrm{CD} 34^{+}$cells but at the same time reduced the migrating ability of $\mathrm{S} / \mathrm{G}_{2} / \mathrm{M}$ cells, whose binding capacity was upregulated as compared with cells in $\mathrm{G}_{0} / \mathrm{G}_{1}$.

Adhesive and migratory activities of ex vivo-cultured $\mathrm{CB}$ $\mathrm{CD}_{4}{ }^{+}$cells were compared with those of unstimulated CD34 ${ }^{+}$ cells (Table 1). Adhesion to Fn was higher after 48 hours of ex vivo culture $(P<.05)$. Migration toward MS-5 CM across Fn declined significantly $(P<.05)$, while no changes in motility were observed in BSA-coated transwells. This confirms a specific change in Fn interaction during cell cycle progression of progenitor cells ex vivo.

It has been suggested that culture of hematopoietic cells with Fn causes accelerated cell cycle progression. ${ }^{20,35,36}$ To exclude the possibility that contact with Fn by itself was responsible for the higher cycling status of adherent or nonmigrating cells (ie, cells staying in contact with Fn throughout adhesion or migration

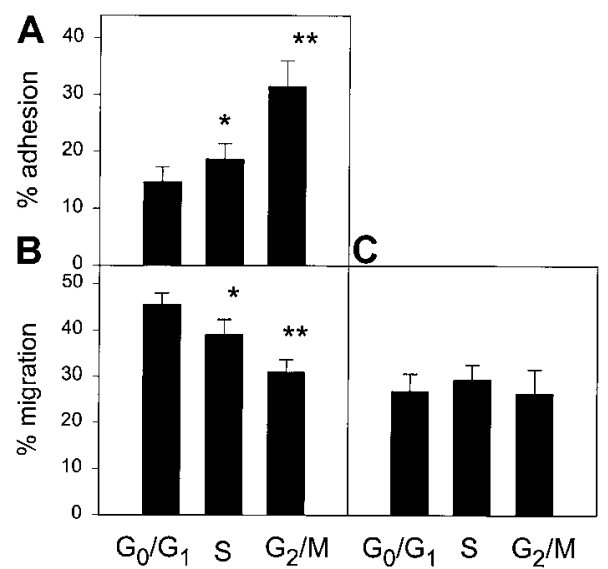

Figure 5. Adhesion and migration of cultured $\mathrm{CD}_{3} 4^{+}$residing in different phases of the cell cycle. CB CD $34^{+}$cells were cultured ex vivo for 48 hours and assayed for Fn binding ( $n=18[A])$ or migration toward MS- 5 CM across Fn- $(n=6$ $[B]$ ) or BSA-coated filters $(n=6[C])$. Percent adhesion or migration of cells in $G_{0} / G_{1}$, $S$, and $G_{2} / M$ was calculated relative to the total number of cells in each phase in the input population. (A) *Adhesion was statistically higher in $S$ than in $\mathrm{G}_{0} / \mathrm{G}_{1}(P<.05)$; **adhesion was statistically higher in $\mathrm{G}_{2} / \mathrm{M}$ than in $\mathrm{G}_{0} / \mathrm{G}_{1}$ and in $\mathrm{S}(P<.05)$. (B) ${ }^{*}$ Migration was statistically lower in $\mathrm{S}$ than in $\mathrm{G}_{0} / \mathrm{G}_{1}(P<.05)$; ${ }^{* *}$ migration was statistically lower in $\mathrm{G}_{2} / \mathrm{M}$ than in $\mathrm{G}_{0} / \mathrm{G}_{1}$ and in $\mathrm{S}(P<.05)$
Table 1. Adhesion and migration of unstimulated and ex vivo-expanded CD34 ${ }^{+}$cells

\begin{tabular}{lcc}
\hline & \multicolumn{2}{c}{ Cell fraction } \\
\cline { 2 - 3 } & Freshly isolated & Ex vivo-activated \\
\hline \% adhesion & $14.2 \pm 3.9$ & $36.6 \pm 5.5^{*}$ \\
$\%$ migration (Fn) & $61.3 \pm 3.8$ & $37.6 \pm 1.2^{*}$ \\
$\%$ migration (BSA) & $25.1 \pm 1.2$ & $21.5 \pm 0.7$ \\
\hline
\end{tabular}

Freshly isolated and ex vivo-activated $\mathrm{CD}_{3} 4^{+}$cells were assayed for adhesion on Fn. The migration capacity toward MS-5 CM of each fraction was measured in Fnand BSA-coated transwells $(n=3)$.

${ }^{\star} P<.05$ compared with freshly isolated $\mathrm{CD} 34^{+}$cells.

assays), activated CD34+ cells were stained with Hoechst 33342 and sorted into $G_{0} / G_{1}$ and $S / G_{2} / M$ subpopulations before measuring the adhesive and migratory capacities of each fraction separately. Cycling cells had a 3 -fold higher adhesion capacity $(50.2 \% \pm 5.1 \%)$ compared with noncycling cells $(16.0 \% \pm 2.2 \%$, $P<.05$ ) (Figure 6).Transmigration toward MS-5 CM across BSA was similar for cycling $(19.0 \% \pm 1.1 \%$ migration $)$ and noncycling cells $(19.4 \% \pm 0.9 \%$ migration, $P>.05)$, whereas in Fn-coated transwells cycling cells had a reduced migratory capacity as compared with the noncycling cells $(13.8 \% \pm 2.0 \%$ vs $33.3 \% \pm 5.8 \%, P<.05$ ) (Figure 6). Migration of cycling cells across Fn was even significantly lower than across BSA $(13.8 \% \pm 2.0 \%$ vs $19.0 \pm 1.1 \%, P<.05)$. This further suggests that full adhesion to Fn of cycling $\mathrm{CD} 34^{+}$cells inhibited their migration.

\section{Defective migration of cycling LTC-ICs}

Transwell assays toward MS-5 CM were set up with cultured $\mathrm{CD} 34^{+}$cells. Cells recovered in the nonmigrating and migrating fractions were replated in secondary LTC-IC assays. Migration of

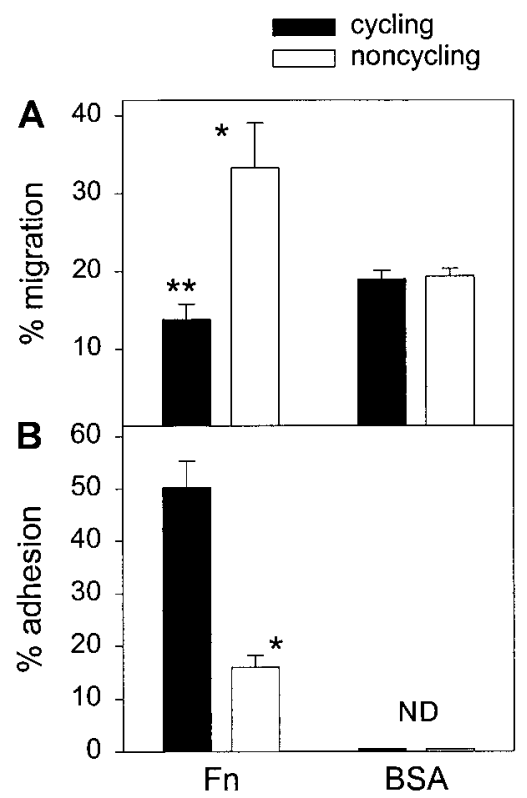

Figure 6. Adhesion and migration of FACS-sorted cycling and noncycling CD34 ${ }^{+}$cells. Cultured $\mathrm{CD} 34^{+}$cells were fractionated into noncycling $\left(\mathrm{G}_{0} / \mathrm{G}_{1}\right)$ and cycling $\left(S / G_{2} / M\right)$ fractions by Hoechst sorting $(n=3)$. (A) Transmigration of cycling and noncycling cells toward MS-5 CM was determined across Fn- or BSA-coated filters. *Migration of noncycling cells was higher than that of cycling cells $(P<.0 .5)$; ${ }^{* *}$ migration of cycling cells across Fn was lower than across BSA $(P<.0 .5)$. (B) Both fractions were assayed for adhesion to Fn- or BSA-coated plates. ${ }^{*} \mathrm{Fn}$ binding of cycling cells was higher than that of noncycling cells $(P<.05)$. ND indicates not detected. 
LTC-ICs toward MS-5 CM was similar across BSA$(40.5 \% \pm 6.4 \%)$ and Fn-coated transwells $(40.8 \% \pm 4.7 \%, \mathrm{n}=3)$. Thus, contrary to what was observed for committed progenitors, Fn appeared to have no enhancing effect on the transmigration of overall LTC-ICs.

The cell cycle status of LTC-ICs recovered in the migrating and nonmigrating fractions was determined by HU killing assays (Figure 7). In the presence of Fn, migration of noncycling LTC-ICs was $48.0 \% \pm 2.9 \%$ while only $20.5 \% \pm 1.1 \%$ of cycling LTC-ICs were able to migrate toward MS-5 CM $(P<.05, \mathrm{n}=4)$. On the opposite, in BSA-coated transwells, migration was increased in cycling LTC-ICs $(53.7 \% \pm 5.2 \%)$, compared with noncycling LTC-ICs $(27.9 \% \pm 1.4 \%)(P<.05, \mathrm{n}=4)$. Thus, Fn had a positive effect on the migration of noncycling LTC-ICs and an inhibitory effect on that of cycling LTC-ICs. We had previously reported that Fn binding is 3-fold higher in cycling LTC-ICs compared with their noncycling counterparts. ${ }^{27}$ Overall, our data suggest that the inverse relationship between adhesion and migration of cycling progenitor cells holds true for the more primitive LTC-IC subset.

\section{Adhesion and migration of cycling CD $34^{+}$cells are independently regulated by VLA- 4 and VLA- 5 integrins in dividing cells}

Activated $\mathrm{CD} 34^{+}$cells were preincubated with nonspecific IgG or with antibodies blocking either VLA-4 or VLA-5 and assayed for transmigration activity. In all assays, the cell cycle status of migrating and nonmigrating cells was assessed by PI staining to establish whether the effect of blocking antibodies was present in all phases of the cell cycle (Figure 8A). Interestingly, while the inhibition provided by anti-VLA-4 antibody was similar in $\mathrm{G}_{0} / \mathrm{G}_{1}$ $\left(22.3 \% \pm 4.0 \%\right.$ inhibition), in $S(26.1 \% \pm 8.5 \%)$, and in $\mathrm{G}_{2} / \mathrm{M}$ $(17.6 \% \pm 6.0 \%)(\mathrm{n}=5, P>.05)$, anti-VLA-5 antibody was less effective in blocking migration of cells in $\mathrm{G}_{2} / \mathrm{M}(9.9 \% \pm 4.6 \%$ inhibition) compared with cells in $\mathrm{G}_{0} / \mathrm{G}_{1}(36.2 \% \pm 2.6 \%, P<.05)$ or in $\mathrm{S}$ phase $(40.3 \% \pm 6.6 \%, P<.05)$.

Similar experiments were performed to establish the contribution of VLA-4 and VLA-5 in mediating adhesion of activated $\mathrm{CD} 4^{+}$cells in various phases of the cell cycle. Anti-VLA-4 treatment resulted in $30.9 \% \pm 11.1 \%$ inhibition of Fn binding in $\mathrm{G}_{0} / \mathrm{G}_{1}$ and $38.3 \% \pm 1.1 \%$ in $\mathrm{S}$ phase, whereas no inhibition was

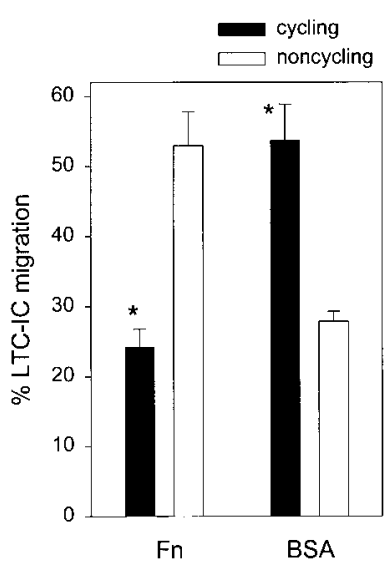

Figure 7. Migration of cycling and noncycling LTC-ICs. Transmigration toward MS-5 CM of cultured CD34+ cells was determined across BSA- or Fn-coated filters. Migrating and nonmigrating cells were replated in LTC-IC assays. The cycling fraction of LTC-ICs was measured by HU killing assays. Data represent percent migration of cycling and noncycling LTC-ICs $(n=4) .{ }^{*} P<.05$ compared with noncycling LTC-IC either across Fn or BSA.

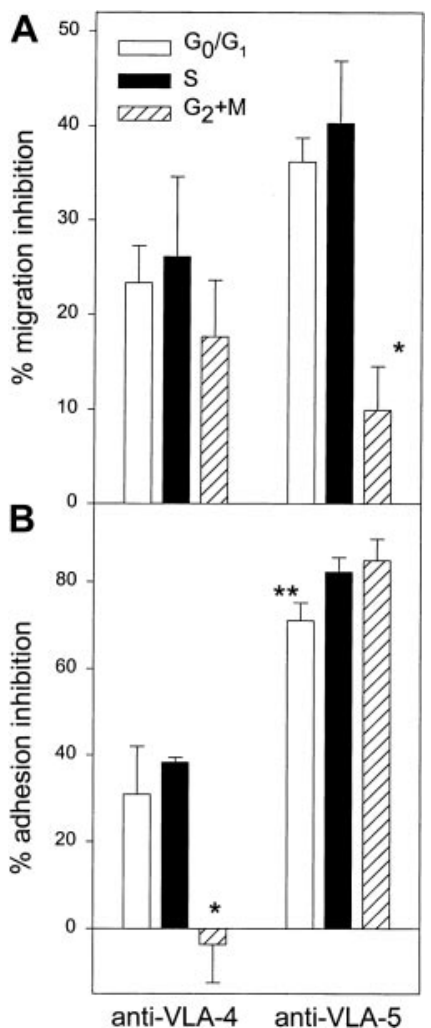

Figure 8. Role of VLA-4 and VLA- 5 in mediating adhesion and transmigration of CD34 ${ }^{+}$cells in different phases of the cell cycle. (A) Migration of cultured CD34 ${ }^{+}$ cells toward MS-5 CM was assayed in Fn-coated transwells during 3 hours, after which cell cycle status of nonmigrating and migrating cells was determined by $\mathrm{PI}$ staining. Prior to transmigration, cells were incubated with blocking antibodies against VLA-4 or VLA-5 integrins. Control cells were treated with isotype-matched control IgG. Percent inhibition of migration was calculated for cells in $G_{0} / G_{1}, S$, and $\mathrm{G}_{2} / \mathrm{M}(\mathrm{n}=5)$. *Inhibition by anti-VLA- 5 was lower in $\mathrm{G}_{2} / \mathrm{M}$ cells compared with $\mathrm{S}$ or $\mathrm{G}_{0} / \mathrm{G}_{1}$ cells $(P<.05)$. (B) Adhesion of cultured $\mathrm{CD} 34^{+}$cells to $\mathrm{Fn}$ was measured after neutralization of VLA-4 or VLA-5 by blocking antibodies or incubation with control $\mathrm{lgG}$. After 1-hour adhesion, the cell cycle status of adherent and nonadherent cells was determined by PI staining. Data represent the percent inhibition of Fn binding compared with control IgG in each phase of the cell cycle $(n=4)$. *Inhibition of $F n$ binding by anti-VLA-4 was lower in $\mathrm{G}_{2} / \mathrm{M}$ compared with $\mathrm{S}$ and $\mathrm{G}_{0} / \mathrm{G}_{1}$ cells $(P<.05)$. ${ }^{*}$ Inhibition of $\mathrm{Fn}$ binding by anti-VLA-5 was lower in $\mathrm{G}_{0} / \mathrm{G}_{1}$ compared with $\mathrm{S}$ and $\mathrm{G}_{2} / \mathrm{M}(P<.05)$.

observed for cells in $\mathrm{G}_{2} / \mathrm{M}$ (Figure $8 \mathrm{~B}$ ). Anti-VLA-5 was slightly more effective in blocking cells in $\mathrm{S}(82.2 \% \pm 3.3 \%$ inhibition $)$ and $\mathrm{G}_{2}+\mathrm{M}(84.9 \% \pm 5.0 \%)$, compared with $\mathrm{G}_{0} / \mathrm{G}_{1}$ cells $(71.0 \% \pm 4.1 \%$ inhibition, $P<.05)$.

When comparing migration and adhesion data, the most striking difference was observed for $\mathrm{CD}_{3} 4^{+}$cells in $\mathrm{G}_{2} / \mathrm{M}$ : VLA-5 mediated strong adhesion but not migration of $\mathrm{G}_{2} / \mathrm{M}$ cells, while the reverse was shown for VLA-4, ie, VLA-4 was involved in migration but not in static adhesion of this cell subset. Altogether, these results suggest that the effect of VLA- 4 and VLA- 5 integrins in mediating adhesion and migration of stimulated progenitor cells onto Fn was modulated in relationship to cell cycle status and independently of each other.

\section{Chemotaxis of VLA-5 dim and VLA-5 $5^{\text {high }}$ cells subfractionated on} the basis of cell cycle status

The observation of a subset of $\mathrm{CD} 34^{+} \mathrm{CXCR} 4^{+} \mathrm{VLA}-5^{\text {high }}$ cells unable to migrate across Fn (Figure 4) led us to speculate that maximal VLA-5 expression induced static adhesion to Fn and defective motility. To test this hypothesis, $\mathrm{CD} 34^{+}$cells were sorted 
into VLA-5 $5^{\text {high }}$ and VLA-5 $5^{\text {low }}$ subsets using a nonblocking antibody (clone VC5; Pharmingen), and migration of both fractions toward MS-5 CM was assayed across Fn and BSA (Table 2). Migration across Fn was higher in the CD $34^{+}$VLA-5 ${ }^{\text {low }}$ compared with the CD $34^{+}$VLA- $5^{\text {high }}$ fraction $(P<.05)$, while migration of each subset was similar across BSA. However, compared with the VLA- $5^{\text {dim }}$ fraction, the VLA- $5^{\text {high }}$ fraction had a 2-fold enrichment in cycling cells, which might then underlie their defective migration capacity. Similar findings have already been reported in murine HSCs fractionated on the basis of VLA-5 and other adhesion molecules ${ }^{37}$ and are mostly due to larger size and higher fluorescence background of cycling cells compared with noncycling cells.

To analyze independently the effect of cycle status and VLA-5 expression on transmigration across Fn, CD $34^{+} \mathrm{VLA}-5^{\text {dim }}$ and CD $34^{+}$VLA- $5^{\text {high }}$ cells were each subfractionated into $G_{0} / G_{1}$ and $\mathrm{S} / \mathrm{G}_{2}+\mathrm{M}$ fractions (Figure 9 ). The migratory activity of each of the 4 fractions was assessed toward MS-5 CM across Fn-coated transwells (Table 3 ). The data clearly show that the expression level of VLA-5 had no influence on the chemotaxis of activated CD34 ${ }^{+}$ cells across Fn, while transit in $\mathrm{S} / \mathrm{G}_{2}+\mathrm{M}$ negatively affected cell motility independently of VLA-5 expression density.

\section{Discussion}

In this report, we have shown that cycling committed progenitor cells as well as LTC-ICs harvested after a 2-day expansion culture presented defective migration across Fn toward MS-5 CM. We can rule out the hypothesis that $\mathrm{G}_{0} / \mathrm{G}_{1}$ progenitor cells passively migrate at a higher rate because of their smaller size. Indeed, the higher migration rate of noncycling progenitor cells was observed when the transwell filter was coated with Fn whereas, across BSA-coated filters, migration of noncycling progenitor cells was similar, or even lower in the case of LTC-ICs, compared with that of their cycling counterparts. The impaired migratory activity of cycling progenitor cells was not due to a reduced response to SDF-1 because, again, migration across BSA toward MS-5 CM was not defective in this cell population. Thus, the migration defect of cycling progenitor cells was observed as a result of an active interaction with Fn. Indeed, when adhesion to Fn was studied in relation to cell cycle status, it was observed that adhesion of cycling committed progenitor cells and LTC-ICs was higher compared with their noncycling counterparts.

A number of studies have been devoted to delineating the different factors influencing migration rate..$^{30,38}$ Migration requires coordinated attachment of the cell front and release of binding sites at the cell rear. Cell-substratum adhesion strength is critical to this process because strong binding will retain cells while lower adhesive force will allow contact with the matrix and easier

Table 2. Migration of CD34+ cells expressing low and high levels of VLA-5

\begin{tabular}{lcc}
\hline & \multicolumn{2}{c}{ Cell fraction } \\
\cline { 2 - 3 } & VLA-5 low & VLA-5 high $^{\text {low }}$ \\
\hline \% $/ \mathrm{G}_{2}+$ M cells & $34.6 \pm 1.0$ & $62.0 \pm 1.9$ \\
Fn & & \\
BSA & $38.7 \pm 1.7^{*}$ & $20.0 \pm 3.4$ \\
& $24.1 \pm 3.4$ & $26.2 \pm 1.3$ \\
\hline
\end{tabular}

Cultured $\mathrm{CD}_{3} 4^{+}$cells were sorted into VLA-5low and VLA-5 high fractions. The percent cells in $S / G_{2}+M$ was determined in each fraction by PI staining. The migration capacity was assessed toward MS- 5 CM across Fn $(n=6)$ or BSA $(n=2)$.

${ }^{*} P<.05$ compared with migration of VLA- $5^{\text {high }}$ cells across Fn.
A

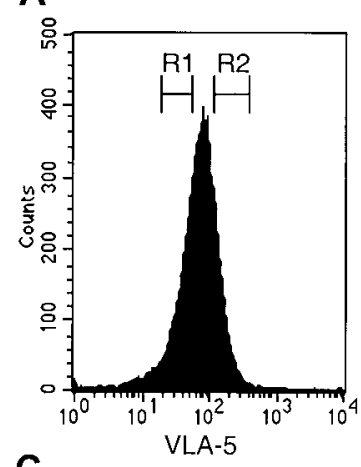

C

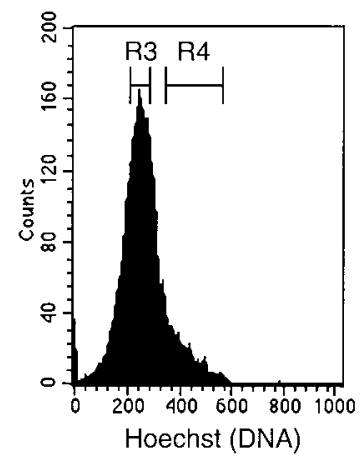

B
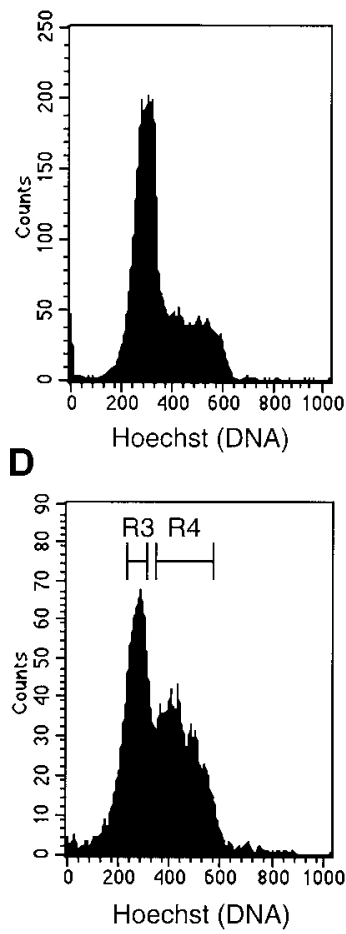

Figure 9. Fractionation of cultured CD $34^{+}$cells on the basis of VLA-5 expression and cell cycle status. Cultured $\mathrm{CD} 34^{+}$cells were simultaneously labeled with anti-VLA-5 and Hoechst 33342. (A) VLA-5 histogram showing gating of CD34+ $V_{L} A^{\text {low }}(R 1)$ and VLA-5 high $(R 2)$ cells. (B) DNA histogram of total CD34+ cells. (C) DNA histogram of CD34 ${ }^{+} \mathrm{VLA}-5^{\text {low }}$ cells. (D) DNA histogram of CD $34^{+} \mathrm{VLA}-5^{\text {high }}$ cells. In each of VLA-5 ${ }^{\text {low }}$ and VLA-5 $5^{\text {high }}$ subsets, noncycling (R3) and cycling (R4) CD34 ${ }^{+}$ cells were sorted.

detachment of adhesion complexes. The differences in adhesion and migration described here in cycling and noncycling cells may thus indicate that adhesion strength to Fn increases during cell cycle transit, leading to static binding and impairment of cell migration.

It has been shown that bone marrow implantation is dependent on intramedullary migration followed by selective retention in specific endosteal niches. ${ }^{24}$ If we assume that migration and adhesion require balanced interactions of both VLA-4 and VLA-5 with Fn, our data may suggest that inactivation of VLA-5mediated migration of progenitor cells in $\mathrm{G}_{2} / \mathrm{M}$ may lead to a selective homing defect, while the inability of VLA-4 to mediate static binding to $\mathrm{Fn}$ in $\mathrm{G}_{2} / \mathrm{M} \mathrm{CD} 34^{+}$cells might result in defective retention in the bone marrow. Conversely, VLA-4 and VLA-5 were simultaneously active in other phases of the cell cycle, in both

Table 3. Migration across Fn of $\mathrm{CD} 34^{+}$cells fractionated on the basis of VLA- 5 expression and cell cycle status

\begin{tabular}{|c|c|c|c|c|}
\hline \multirow{3}{*}{$\begin{array}{c}\text { Experiment } \\
\text { no. }\end{array}$} & \multicolumn{4}{|c|}{ Cell fraction } \\
\hline & \multicolumn{2}{|c|}{$\mathrm{CD} 34^{+}$VLA-5 $5^{\text {low }}$} & \multicolumn{2}{|c|}{$\mathrm{CD} 34^{+}$VLA-5 $5^{\text {high }}$} \\
\hline & $\mathrm{G}_{0} / \mathrm{G}_{1}$ & $\mathrm{~S} / \mathrm{G}_{2}+\mathrm{M}$ & $\mathrm{G}_{0} / \mathrm{G}_{1}$ & $\mathrm{~S} / \mathrm{G}_{2}+\mathrm{M}$ \\
\hline 1 & 39.0 & 24.5 & 38.2 & 17.2 \\
\hline 2 & 43.6 & 26.7 & 35.8 & 27.1 \\
\hline 3 & 40.3 & 19.9 & 40.0 & 22.7 \\
\hline Mean & $40.9^{*}$ & 23.7 & $38.0^{*}$ & 22.3 \\
\hline SEM & 1.4 & 2.0 & 1.2 & 2.9 \\
\hline
\end{tabular}

Cultured $\mathrm{CD}_{3} 4^{+}$cells were sorted as depicted in Figure 9 into 4 fractions. Data represent percent migration of each fraction across Fn toward MS-5 CM.

${ }^{*} P<.05$ compared with $\mathrm{S} / \mathrm{G}_{2}+\mathrm{M}$ in both VLA-5 ${ }^{\text {low }}$ and VLA-5 ${ }^{\text {high }}$ subsets. 
adhesion and migration assays. It should be noted, however, that because LTC-ICs represent a small fraction of total CD $34^{+}$cells, we cannot provide direct evidence that the observed changes of integrin function with cell cycle status in cultured $\mathrm{CD} 34^{+}$cells were also present at the LTC-IC level.

When comparing the behavior of committed progenitors and of LTC-ICs in transmigration assays, it was observed that migration of LTC-ICs toward MS-5 CM across BSA was higher than that of $\mathrm{CD} 34^{+}$cells. This may suggest that LTC-ICs are more responsive to SDF-1 than more committed progenitors, which is in accordance with data reported by Peled et al ${ }^{39}$ showing that among the $\mathrm{CD} 34^{+}$ population the $\mathrm{CD} 38^{\text {low }}$ subset had an increased migratory activity toward SDF-1. In addition, Fn coating of the transwell filter was not effective in stimulating LTC-IC migration toward MS-5 CM above levels observed across BSA-coated filters, whereas in more committed progenitors Fn induced a 2-fold increase in migratory activity. This difference may result from stronger adhesion of LTC-ICs than of colony-forming cells to Fn, as described in a previous paper by our group ${ }^{27}$ and in other reports. ${ }^{40}$ Fn may increase migration of mildly adherent LTC-ICs while retaining strongly adherent LTC-ICs onto the filter, with no net change in overall LTC-IC migration.

Yong and coworkers ${ }^{41,42}$ have studied the migratory activity of unstimulated and stimulated progenitor cells isolated from various sources. A consistent finding of these studies was that proliferating progenitor cells migrated more efficiently than nonproliferating ones. This difference with our results may arise from the fact that migration was assessed across endothelial cells by Yong and colleagues whereas in the present work migration was studied in Fn-coated transwells. Thus, it is not possible to draw general rules on the migration ability of cycling and noncycling progenitor cells Instead, it is likely that the transmigratory activity will depend on the cell type or the extracellular matrix protein across which migration occurs. In addition, transendothelial migration may represent initial stages of homing, while migration across Fn may be more important for the final localization of stem/progenitor cells in the bone marrow environment. Therefore, extrapolation of these data to in vivo homing mechanisms must be done cautiously.

An apparent discrepancy in our results is that most of the changes in migration of total $\mathrm{CD} 34^{+}$cells occurred during the
$\mathrm{G}_{2} / \mathrm{M}$ phase while, in the LTC-IC subset, a similar modulation was observed during $\mathrm{S}$ phase. We assume that these differences are due to different procedures used for cell cycle phase identification. In LTC-IC experiments, cells were treated with HU, which selectively eliminates cells in $\mathrm{S}$ phase, prior to the migration assay. We believe that results obtained with this procedure demonstrate unambigously that LTC-ICs in S phase have decreased migratory activity across Fn. In the case of total $\mathrm{CD} 34^{+}$cells, cells were allowed to migrate, after which the cell cycle status of migrating and nonmigrating cells was determined by PI staining. Our results show a gradual decrease in migration during transit from $G_{1}$ to $S$ and from $S$ to $G_{2} / M$. Thus, it may be possible that during a 3-hour migration assay $\mathrm{S}$ phase cells remained in the top chamber and gradually accumulated in $\mathrm{G}_{2} / \mathrm{M}$, which then would lead to an overestimation of the migration defect of $\mathrm{G}_{2} / \mathrm{M}$ cells. This hypothesis is supported by another study in which we have shown that synchronized $\mathrm{CD} 34^{+}$cells execute a complete transition from mid $\mathrm{S}$ phase to $\mathrm{G}_{2} / \mathrm{M}$ in approximately 3 hours. ${ }^{43}$

The data presented in this paper have important implications for the engraftment of ex vivo-expanded progenitor cells. It has been suggested by different authors that VLA-5 plays a physiologic role in stem cell trafficking. ${ }^{10,15,37,44}$ Because other studies have observed an engraftment defect of cycling stem/progenitor cells, our data may suggest that this is partly caused by increased static adhesion and impaired motility across Fn. Whether such a phenomenon applies to the interaction of cycling progenitor cells to other adhesion molecules remains the subject of further studies and should provide more detailed knowledge of the homing mechanisms of expanded HSCs.

\section{Acknowledgments}

The authors thank Dr E. Ponthier and all the nurses and physicians of the obstetrical department of the Clinique St Joseph, Liège, for providing $\mathrm{CB}$ samples. The expert technical assistance of $\mathrm{M}$. Lenjou, Antwerp University Hospital, in Hoechst sorting is also acknowledged.

\section{References}

1. Peters SO, Kittler EL, Ramshaw HS, Quesenberry PJ. Murine marrow cells expanded in culture with IL-3, IL-6, IL-11, and SCF acquire an engraftment defect in normal hosts. Exp Hematol. 1995:23:461-469.

2. Ramshaw HS, Rao SS, Crittenden RB, et al. Engraftment of bone marrow cells into normal unprepared hosts: effects of 5-fluorouracil and cell cycle status. Blood. 1995;86:924-929.

3. Peters SO, Kittler EL, Ramshaw HS, Quesenberry PJ. Ex vivo expansion of murine marrow cells with interleukin-3 (IL-3), IL-6, IL-11, and stem cell factor leads to impaired engraftment in irradiated hosts. Blood. 1996;87:30-37.

4. Kittler EL, Peters SO, Crittenden RB, et al. Cytokine-facilitated transduction leads to low-level engraftment in nonablated hosts. Blood. 1997;90 865-872.

5. Habibian HK, Peters SO, Hsieh CC. et al. The fluctuating phenotype of the lymphohematopoietic stem cell with cell cycle transit. J Exp Med. 1998;188:393-398.

6. Szilvassy SJ, Meyerrose TE, Grimes B. Effects of cell cycle activation on the short-term engraftment properties of ex vivo expanded murine hematopoietic cells. Blood. 2000;95:2829-2837.
7. Gothot A, van der Loo JCM, Clapp DW, Srour EF. Cell cycle-related changes in repopulating capacity of human mobilized peripheral blood CD34+ cells in NOD/SCID mice. Blood. 1998;92:26412649.

8. Glimm H, Oh IH, Eaves CJ. Human hematopoietic stem cells stimulated to proliferate in vitro lose engraftment potential during their S/G(2)/M transit and do not reenter $\mathrm{G}(0)$. Blood. 2000;96: 4185-4193.

9. Peled A, Grabovsky V, Habler L, et al. The chemokine SDF-1 stimulates integrin-mediated arrest of CD34(+) cells on vascular endothelium under shear flow. J Clin Invest. 1999;104:11991211.

10. Peled A, Kollet O, Ponomaryov T, et al. The che mokine SDF-1 activates the integrins LFA-1, VLA-4, and VLA-5 on immature human CD34(+) cells: role in transendothelial/stromal migration and engraftment of NOD/SCID mice. Blood. 2000;95:3289-3296.

11. Simmons PJ, Masinovsky B, Longenecker BM, et al. Vascular cell adhesion molecule-1 expressed by bone marrow stromal cells mediates the binding of hematopoietic progenitor cells. Blood. 1992:80:388-395
12. Papayannopoulou T, Nakamoto B. Peripheralization of hemopoietic progenitors in primates treated with anti-VLA4 integrin. Proc Natl Acad Sci U S A. 1993;90:9374-9378.

13. Nilsson SK, Debatis ME, Dooner MS, et al. Immunofluorescence characterization of key extracellular matrix proteins in murine bone marrow in situ. J Histochem Cytochem. 1998;46:371-377.

14. Williams DA, Rios M, Stephens C, Patel VP. Fibronectin and VLA-4 in haematopoietic stem cellmicroenvironment interactions. Nature. 1991;352: 438-441.

15. van der Loo JC, Xiao X, McMillin D, et al. VLA-5 is expressed by mouse and human long-term repopulating hematopoietic cells and mediates adhesion to extracellular matrix protein fibronectin. J Clin Invest. 1998;102:1051-1061.

16. Kovach NL, Lin N, Yednock T, Harlan JM, Broudy VC. Stem cell factor modulates avidity of $\alpha 4 \beta 1$ and $\alpha 5 \beta 1$ integrins expressed on hematopoietic cell lines. Blood. 1995:85:159-167.

17. Levesque JP, Leavesley DI, Niutta S, Vadas M, Simmons PJ. Cytokines increase human hematopoietic cell adhesiveness by activation of very late antigen (VLA)-4 and VLA-5 integrins. J Exp Med. 1995:181:1805-1815. 
18. Schofield KP, Rushton G, Humphries MJ, Dexter TM, Gallagher JT. Influence of interleukin-3 and other growth factors on $\alpha 4 \beta 1$ integrin-mediated adhesion and migration of human hematopoietic progenitor cells. Blood. 1997;90:1858-1866.

19. Cui L, Ramsfjell V, Borge OJ, et al. Thrombopoietin promotes adhesion of primitive human hemopoietic cells to fibronectin and vascular cell adhesion molecule-1: role of activation of very late antigen (VLA)-4 and VLA-5. J Immunol. 1997; 159:1961-1969.

20. Levesque JP, Haylock DN, Simmons PJ. Cytokine regulation of proliferation and cell adhesion are correlated events in human CD34+ hemopoietic progenitors. Blood. 1996;88:1168-1176.

21. Prosper F, Stroncek D, McCarthy JB, Verfaillie $\mathrm{CM}$. Mobilization and homing of peripheral blood progenitors is related to reversible downregulation of $\alpha 4 \beta 1$ integrin expression and function. J Clin Invest. 1998;101:2456-2467.

22. Strobel ES, Mobest D, von Kleist S, et al. Adhesion and migration are differentially regulated in hematopoietic progenitor cells by cytokines and extracellular matrix. Blood. 1997;90:3524-3532.

23. Voermans $C$, Gerritsen WR, von dem Borne AE van der Schoot CE. Increased migration of cord blood-derived CD34+ cells, as compared to bone marrow and mobilized peripheral blood CD34+ cells across uncoated or fibronectin-coated filters. Exp Hematol. 1999;27:1806-1814.

24. Nilsson SK, Johnston HM, Coverdale JA. Spatial localization of transplanted hemopoietic stem cells: inferences for the localization of stem cell niches. Blood. 2001;97:2293-2299.

25. Yamaguchi M, Ikebuchi K, Hirayama F, et al. Different adhesive characteristics and VLA-4 expression of CD34+ progenitors in G0/G1 versus $\mathrm{S}+\mathrm{G} 2 / \mathrm{M}$ phases of the cell cycle. Blood. 1998; 92:842-848.

26. Becker PS, Nilsson SK, Li Z, et al. Adhesion receptor expression by hematopoietic cell lines and murine progenitors: modulation by cytokines and cell cycle status. Exp Hematol. 1999;27:533-541.

27. Giet $O$, Huygen $S$, Beguin $Y$, Gothot A. Cell cycle activation of hematopoietic progenitor cells increases very late antigen-5-mediated adhesion to fibronectin. Exp Hematol. 2001;29:515-524.

28. Giancotti FG, Ruoslahti E. Elevated levels of the $\alpha 5 \beta 1$ fibronectin receptor suppress the transformed phenotype of Chinese hamster ovary cells. Cell. 1990;60:849-859.

29. DiMilla PA, Stone JA, Quinn JA, Albelda SM, Lauffenburger DA. Maximal migration of human smooth muscle cells on fibronectin and type IV collagen occurs at an intermediate attachment strength. J Cell Biol. 1993;122:729-737.

30. Palecek SP, Loftus JC, Ginsberg MH, Lauffenburger DA, Horwitz AF. Integrin-ligand binding properties govern cell migration speed through cell-substratum adhesiveness. Nature. 1997;385: 537-540.

31. Itoh K, Tezuka H, Sakoda H, et al. Reproducible establishment of hemopoietic supportive stromal cell lines from murine bone marrow. Exp Hematol. 1989;17:145-153.

32. Sutherland HJ, Eaves CJ, Eaves AC, Dragowska W, Lansdorp PM. Characterization and partial purification of human marrow cells capable of initiating long-term hematopoiesis in vitro. Blood. 1989;74:1563-1570.

33. Taswell C. Limiting dilution assays for the determination of immunocompetent cell frequencies. J Immunol. 1981;126:1614-1619.

34. Traycoff CM, Abboud MR, Laver J, Clapp DW, Srour EF. Rapid exit from G0/G1 phases of cell cycle in response to stem cell factor confers on umbilical cord blood CD34+ cells an enhanced ex vivo expansion potential. Exp Hematol. 1994; 22:1264-1272.

35. Yokota T, Oritani K, Mitsui H, et al. Growth-supporting activities of fibronectin on hematopoietic stem/progenitor cells in vitro and in vivo: structural requirement for fibronectin activities of $\mathrm{CS} 1$ and cell-binding domains. Blood. 1998;91:32633272.

36. Schofield KP, Humphries MJ, de Wynter E, Testa $\mathrm{N}$, Gallagher JT. The effect of $\alpha 4 \beta 1$-integrin binding sequences of fibronectin on growth of cells from human hematopoietic progenitors. Blood. 1998;91:3230-3238.

37. Orschell-Traycoff CM, Hiatt K, Dagher RN, et al. Homing and engraftment potential of Sca$1(+)$ lin $(-)$ cells fractionated on the basis of adhesion molecule expression and position in cell cycle. Blood. 2000;96:1380-1387.

38. Huttenlocher A, Sandborg RR, Horwitz AF. Adhesion in cell migration. Curr Opin Cell Biol. 1995;7: 697-706.

39. Peled A, Petit I, Kollet O, et al. Dependence of human stem cell engraftment and repopulation of NOD/SCID mice on CXCR4. Science. 1999;283: 845-848.

40. Van der Sluijs JP, Baert MR, Ploemacher RE. Differential adherence of murine hematopoietic stem cell subsets to fibronectin. Exp Hematol. 1994;22: 1236-1243.

41. Yong KL, Watts M, Shaun TN, et al. Transmigration of CD34+ cells across specialized and nonspecialized endothelium requires prior activation by growth factors and is mediated by PECAM-1 (CD31). Blood. 1998;91:1196-1205.

42. Yong K, Fahey A, Reeve L, et al. Cord blood progenitor cells have greater transendothelial migratory activity and increased responses to SDF-1 and MIP-3 $\beta$ compared with mobilized adult progenitor cells. Br J Haematol. 1999;107:441-449.

43. Huygen S, Beguin Y, Gothot A. Regulation of adhesion and migration of human long-term cultureinitiating cells during cell cycle synchronization [abstract]. Exp Hematol. 2000;28:55.

44. Papayannopoulou T, Priestley GV, Nakamoto B, et al. Synergistic mobilization of hemopoietic progenitor cells using concurrent $\beta 1$ and $\beta 2$ integrin blockade or $\beta 2$-deficient mice. Blood. 2001;97: $1282-1288$ 